\title{
THE ANALYSIS OF EXTERNAL FACTORS THAT INFLUENCE LEARNING DIFFICULTY IN LEARNING MATHEMATICS FOR GRADE 4 STUDENTS OF SD NEGERI 125 PEKANBARU
}

\author{
Evi Dwinta Wulandari \\ Universitas Riau, Pekanbaru, Indonesia \\ eviwulandari896@gmail.com
}

\begin{abstract}
This research is motivated by a number of students who have difficulty in learning mathematics caused by external factors, including: the attention of family members when learning mathematics, the teacher's method of teaching mathematics, the atmosphere of the home environment, and so on. External factors are very influential on students besides the genetic factors or internal factors. Various problems caused by the stimuli from outside individuals make students experience learning difficulties. This research used descriptive quantitative method that aimed to find out any external factors that affect learning difficulties in learning mathematics for fourth grade students of SD Negeri 125 Pekanbaru. The population of this study consisted of 44 students, with students who received grades below the KKM of 37 students as the sample. Data collection techniques used were documentation and questionnaires. Based on research findings, the external factors influenced the difficulty of learning mathematics for fourth grade students of SD Negeri 125 Pekanbaru. The biggest factor in influencing difficulties in learning mathematics was the teacher's method of teaching mathematics with a percentage of $17.5 \%$.
\end{abstract}

Keywords: external factors, learning difficulties, mathematics learning

\section{ANALISIS FAKTOR-FAKTOR EKSTERNAL YANG MEMPENGARUHI KESULITAN BELAJAR PADA PEMBELAJARAN MATEMATIKA SISWA KELAS IV SD NEGERI 125 PEKANBARU}

\begin{abstract}
ABSTRAK
Penelitian ini dilatarbelakangi oleh banyaknya siswa yang mengalami kesulitan belajar dalam pembelajaran matematika yang disebabkan oleh faktor eksternal yaitu diantaranya; perhatian anggota keluarga pada saat belajar matematika, metode guru dalam mengajar matematika, suasana lingkungan rumah, dan sebagainya. Faktor eksternal ini sangat berpengaruh terhadap diri siswa selain faktor genetik atau faktor yang ada dalam diri siswa. Beragam masalah yang ditimbulkan karena adanya rangsangan-rangsangan dari luar diri siswa sehingga membuat siswa mengalami kesulitan belajar. Penelitian ini menggunakan metode kuantitatif deskriptif yang bertujuan untuk mengetahui faktor-faktor eksternal apa saja yang mempengaruhi kesulitan belajar pada pembelajaran matematika siswa kelas IV SD Negeri 125 Pekanbaru. Populasi penelitian ini terdiri dari 44 siswa, dengan sampel penelitian yaitu siswa yang mendapat nilai dibawah KKM sebanyak 37 siswa. Teknik pengumpulan data yang digunakan adalah dokumentasi dan angket. Berdasarkan data penelitian faktor eksternal memberikan pengaruh terhadap kesulitan belajar matematika siswa kelas IV SD Negeri 125 Pekanbaru. Adapun faktor yang paling besar dalam mempengaruhi kesulitan belajar matematika yaitu metode guru dalam mengajar matematika dengan persentase $17.5 \%$.
\end{abstract}

Kata Kunci: faktor-faktor eksternal, kesulitan belajar, pembelajaran matematika

\begin{tabular}{|c|c|c|}
\hline Submitted & Accepted & Published \\
\hline 03 Februari 2020 & 12 Juli 2020 & 24 Juli 2020 \\
\hline
\end{tabular}

\begin{tabular}{|l|c|c|}
\hline Citation & $:$ & $\begin{array}{c}\text { Wulandari, E.D. (2020). The Analysis of External Factors That Influence Learning Difficulty in Learning Mathematics } \\
\text { for Grade 4 Students of SD Negeri 125 Pekanbaru. Jurnal PAJAR (Pendidikan dan Pengajaran), 4(4), 738-744. } \\
\text { DOI : http://dx.doi.org/10.33578/pjr.v4i2.8035. }\end{array}$ \\
\hline
\end{tabular}

\section{PENDAHULUAN}

Matematika merupakan salah satu pelajaran yang penting untuk diberikan kepada semua siswa mulai dari sekolah dasar sampai dengan perguruan tinggi. Matematika berguna untuk membekali siswa dengan kemampuan menghitung dan mengolah data serta kemampuan memecahkan masalah dalam kehidupan seharihari. Kemampuan tersebut diperlukan agar siswa 
memperoleh, mengelola, dan memanfaatkan informasi untuk bertahan hidup pada keadaan yang selalu berubah, tidak pasti dan kompetitif.

Dalam upaya mencapai tujuan dari pembelajaran matematika terdapat berbagai permasalahan yang menyebabkan tujuan pembelajaran belum tercapai secara maksimal. Salah satu permasalahan dalam pembelajaran matematika yaitu anggapan dari sebagian besar siswa bahwa matematika adalah sulit dan membosankan, sehingga banyak siswa yang kurang menyukai pelajaran matematika bahkan menjadikan matematika sebagai momok yang harus dihindari. Seperti yang diungkapkan oleh Aunurrahman (2010) bahwa dari berbagai bidang studi yang diajarkan di sekolah, matematika merupakan bidang studi yang dianggap paling sulit oleh para siswa, baik yang tidak berkesulitan bela jar dan terlebih lagi bagi siswa yang berkesulitan belajar.

Kesulitan belajar yang dialami siswa dapat disebabkan oleh dua faktor, yaitu faktor internal dan faktor eksternal. Faktor internal adalah faktor yang berasal dari dalam diri siswa yaitu kesehatan, bakat, minat, motivasi, intelegensi, dan lain-lain (Slameto, 2003). Contohnya yaitu siswa kurang memahami materi pelajaran, kurangnya minat dan motivasi siswa dalam belajar, rendahnya daya tanggap siswa dalam menerima pelajaran, dan pandangan negatif siswa terhadap pelajaran matematika. Sedangkan Faktor esternal adalah faktor yang berasal dari luar diri siswa yaitu dari lingkungan sekolah, lingkungan keluarga, dan masyarakat (Slameto, 2003). Contohnya seperti metode mengajar yang kurang tepat, hubungan siswa dengan guru yang kurang baik, hubungan dengan teman yang kurang harmonis, kurangnya

\section{KAJIAN TEORETIS}

Pengertian belajar menurut Slameto (2003) merupakan suatu proses perubahan yaitu perubahan tingkah laku sebagai hasil dari interaksi dengan lingkungannya dalam memenuhi kebutuhan hidupnya. Perubahan-perubahan tersebut akan nyata dalam seluruh aspek tingkah laku. Belajar dapat didefinisikan sebagai proses usaha yang dilakukan seseorang untuk perhatian dari orang tua, dan juga lingkungan belajar yang kurang ideal. Demikian juga halnya dengan siswa kelas IV SD Negeri 125 Pekanbaru. Mereka mengalami kesulitan belajar matematika yang disebabkan oleh faktor eksternal.

Banyak siswa mengalami kesulitan belajar dalam pembelajaran matematika, hal ini terlihat dari pengamatan peneliti di sekolah Pengenalan Lapangan Persekolahan (PLP) khususnya dikelas praktik yaitu kelas IVB. Terlihat bahwa guru selalu marah ketika mengajar pelajaran matematika, keadaan kelas tidak nyaman pada saat belajar, serta lingkungan tempat tinggal mereka yang berdekatan dengan pasar dan mayoritas orang tua mereka tidak pernah memberikan perhatian terhadap anaknya karena sibuk berdagang di pasar. Hal tersebut sangat berpengaruh terhadap keberhasilan belajar siswa. Pada umumnya, siswa menjadikan pelajaran matematika sebagai mata pelajaran yang paling ditakuti. Kurangnya pemahaman siswa terhadap perkalian dan pembagian juga masih rendah. Ketidakpahaman siswa terhadap suatu konsep materi juga menjadi faktor kesulitan belajar. Dalam hal ini, kesulitan belajar diartikan sebagai kesukaran siswa dalam memahami konsep pelajaran matematika yang diberikan oleh guru.

Berdasarkan latar belakang yang telah dikemukakan, maka rumusan masalah dari penelitian ini yakni faktor apa sajakah yang mempenagruhi kesulitan belajar pada pembelajaran matematika siswa kelas IV SD Negeri 125 Pekanbaru. Adapun tujuan dalam penelitia ini yaitu mengetahui faktor-faktor yang mempengaruhi kesulitan belajar pada pembelajaran matematika siswa kelas IV SD Negeri 125 Pekanbaru.

memperoleh suatu perubahan tingkah laku yang baru secara keseluruhan, sebagai hasil pengalamannya sendiri dalam interaksi dengan lingkungannya. Jadi seseorang yang telah melakukan usaha yang berdampak pada perubahan tingkah lakunya berarti seseorang tersebut dikatakan belajar. 
Menurut Mulyono (2010), kesulitan belajar merupakan terjemahan dari istilah bahasa inggris learning disability. Terjemahan tersebut sesungguhnya kurang tepat karena learning artinya belajar dan disability artinya ketidakmampuan. Sehingga terjemahan yang benar seharusnya adalah ketidakmampuan belajar. Sedangakan menurut Bahri (2002), kesulitan belajar adalah suatu kondisi dimana anak didik tidak dapat belajar secara wajar, disebabkan adanya ancaman, hambatan atau gangguan dalam belajar.

Menurut Slameto (2003), dalam bukunya menyebutkan bahwa faktor yang mempengaruhi belajar digolongkan menjadi 2 golongan, yaitu faktor internal dan faktor eksternal. Faktor eksternal dikelompokkan menjadi 3 faktor, yaitu faktor keluarga, faktor sekolah dan faktor masyarakat.

\section{Faktor Keluarga}

Keluarga merupakan lingkungan terdekat bagi anak dan menjadi faktor utama yang memberikan pengaruh besar terhadap perkembangan anak. Biasanya anak akan cenderung meniru gaya atau apapun yang dilakukan keluarganya terutama orang tua. Oleh karena itu, orang tua haruslah menjadi panutan yang baik untuk anak-anaknya. Siswa yang belajar akan menerima pengaruh dari keluarga berupa cara orang tua mendidik, relasi antaranggota keluarga, suasana rumah tangga dan keadaan ekonomi keluarga.

\section{Faktor Sekolah}

Faktor sekolah yang mempengaruhi belajar ini mencakup metode belajar, kurikulum, relasi guru dengan siswa, relasi siswa dengan siswa, disiplin sekolah, pelajaran dan waktu sekolah, standar pelajaran, keadaan gedung, metode belajar dan tugas rumah.

\section{METODE PENELITIAN}

Penelitian ini dilakukan di SD Negeri 125 Pekanbaru yang terletak di jalan Teuku Cik Ditiro, Sudirman. Penelitian ini dilaksanakan pada semester genap 2020/2021. Sampel penelitian ini
Guru dan cara mengajar merupakan faktor yang yang penting bagaimana sikap dan kepribadian guru, tinggi rendahnya pengetahuan yang dimiliki guru, dan bagaimana cara guru menyampaikan pengetahuan itu kepada anak-anak didiknya. Lingkungan sekolah seperti berbagai fasilitas yang tersedia juga sangat menunjang aktfitas kegiatan belajar mengajar yang baik.

\section{Faktor Masyarakat}

Masyarakat merupakan faktor eksternal yang juga berpengaruh terhadap belajar siswa. Pengaruh itu terjadi karena keberadaanya siswa dalam masyarakat. Faktor tersebut sangat mempengaruhi keberhasilan siswa dalam belajar. Siswa lebih sering bermain di warnet untuk bermain game dari pada belajar kelompok dengan temannya. Hal tersebut sangat berdampak terhadap keberhasilan siswa dalam belajar matematika.

Hamzah (2013) memberikan definisi hakikat matematika adalah ilmu yang membahas angka-angka dan perhitungannya, membahas masalah-masalah numerik, mengenai kuatitas dan besaran, mempelajari hubungan pola, bentuk dan struktur, sarana berpikir, kumpulan sistem, struktur dan alat. Menguasai matematika tidak hanya dilihat dari pada unitnya saja seperti aritmatika, akan tetapi apa yang lebih luas yaitu menguasai dan terampil menyelesaikan masalah dengan tahapan tertentu. hal yang paling sederhana yaitu siswa dapat menguraikan langkah-langkah menyelesaikan masalah minimal tiga langkah penyelesaian soal. Tujuan pembelajaran matematika menurut kurikulum 2013 (Kemendikbud, 2013) menekankan pada dimensi pedagogik modern dalam pembelajaran, yaitu menggunakan pendekatan ilmiah. Dalam pembelajaran matematika kegiatan yang dilakukan agar pembelajaran bermakna yaitu mengamati, menanya, mencoba, menalar, menyaji, dan mencipta.

adalah siswa kelas IV SD Negeri 125 Pekanbaru yang mengalami kesulitan belajar matematika ditandai dengan nilai ujian MID Semester yang dibawah nilai KKM yaitu berjumlah 37 siswa. 
Desain penelitian yang digunakan peneliti adalah kuantitatif deskriptif. Bertujuan untuk mengetahui besar persentase dari setiap indikator yang mempengaruhi kesulitan belajar matematika, kemudian hasil persentase tersebut di deskripsikan sesuai data yang diperoleh. Menurut Margono (2000) kuantitatif adalah suatu proses menggunakan data berupa angka sebagai alat menemukan keterangan mengenai apa yang ingin kita ketahui, sedangkan penelitian deskriptif seperti dimaksudkan untuk memberikan ciri-ciri orang tertentu, kelompok-kelompok atau keadaan. Keterangan untuk penelitian seperti ini dapat dikumpulkan dengan bantuan wawancara, kuesioner, dan pengamatan langsung. Metode pengumpulan data menggunakan metode survey. Menurut Sugiyono (2015) bahwa metode survey digunakan untuk mendapatkan data dari tempat tertentu yang alamiah (bukan buatan), tetapi peneliti melakukan perlakuan dalam pengumpulan data, misalnya dengan mengedarkan kuesioner, test, wawancara terstruktur dan sebagainya (perlakuan tidak seperti dalam eksperimen).

Adapun cara pengumpulan data dalam penelitian ini adalah menggunakan angket. Menurut Sugiyono (2015) angket merupakan teknik pengumpulan data yang dilakukan dengan cara memberi pertanyaan atau pernyataan kepada responden. Angket dapat berupa pertanyaan tertutup atau terbuka, dapat diberikan kepada responden secara langsung atau dikirim melalui pos, atau internet. Untuk memperoleh data tentang faktor-faktor eksternal yang mempengaruhi kesulitan belajar pada pembelajaran matematika dalam penelitian ini, maka terdapat beberapa langkah-langkahnya sebagai berikut:

1. Peneliti membuat angket untuk pengumpulan data. Adapun kisi-kisi angket faktor-faktor eksternal yang mempengaruhi kesulitan belajar pada pembelajaran matematika berjumlah 24 pernyataan.

2. Peneliti melakukan uji validasi butir instrumen menggunakan expert judgment.

3. Peneliti melakukan penyebaran angket ke Sekolah Dasar Negeri 125 Pekanbaru.

4. Peneliti merekapitulasi hasil validitas instrumen tersebut.

Data yang diperoleh dari penyebaran angket kepada siswa diolah dengan perhitungan persentase. Menurut Sudjiono (2011) Rumusnya adalah sebagai berikut:

Keterangan:

$$
\mathrm{P}=\frac{f}{\mathrm{~N}} \times 100 \%
$$

$\mathrm{P}=$ Angka presentase

$\mathrm{f}=$ skor yang diperoleh responden

$\mathrm{N}=$ Skor maksimal

Selanjutnya untuk menentukan skor pada setiap sub indikator dengan memakai rumus persentase yang dikemukakan oleh Sugiyoono (dalam Weni Zulkaidah, 2018) sebagai berikut:

$$
\mathrm{PC}=\frac{\mathrm{sc}}{\mathrm{si}} \times 100 \%
$$

Keterangan:

$\mathrm{PC}=$ Persentase capaian

Fsc $=$ Jumlah skor capaian responden per sub indicator

$\mathrm{Si}=$ Jumlah skor maksimal

Berikut kriteria penilaian yang dihitung dari hasil yang di peroleh pada setiap item, melalui skor dikemukakan Sugiyono (2010) sebagai berikut:

Tabel 1. Persentase Kriteria Penskoran Respon Siswa

Interval Kriteria

$\begin{array}{cc}76 \%-100 \% & \text { Sangat Sering } \\ 51 \%-75 \% & \text { Sering } \\ 25 \%-50 \% & \text { Jarang } \\ 0 \%-25 \% & \text { Tidak Pernah }\end{array}$




\section{HASIL DAN PEMBAHASAN}

Hasil dari rekapitulasi analisis faktorfaktor eksternal yang mempengaruhi kesulitan belajar pada pembelajaran matematika siswa kelas

IV SD Negeri 125 Pekanbaru per sub indikator dapat dilihat pada tabel dibawah ini:

Tabel 2. Rekapitulasi Faktor Eksternal yang Mempengaruhi Kesulitan Belajar pada Pembelajaran Matematika

\begin{tabular}{clcc}
\hline No & \multicolumn{1}{c}{ Sub Indikator } & Persentase Capaian & Persentase Keseluruhan \\
\hline 1. & Perhatian anggota keluarga pada saat anak & $52.7 \%$ & $12.0 \%$ \\
2. & Celajar matematika & $62.2 \%$ & $14.2 \%$ \\
3. & Fara orang tua mendiditik belajar matematika & $49.8 \%$ & $11.4 \%$ \\
4. & Metode guru dalam mengajar matematika & $76.6 \%$ & $17.5 \%$ \\
5. & Suasana kelas selama pembelajaran & $75.3 \%$ & $17.2 \%$ \\
& matematika & $64.1 \%$ & $14.6 \%$ \\
6. & Teman bermain diluar jam sekolah & $57.4 \%$ & $13.1 \%$ \\
7. & Suasana lingkungan rumah & $438.1 \%$ & $100 \%$ \\
\hline
\end{tabular}

Berdasarkan data di atas dapat diketahui faktor-faktor eksternal yang mempengaruhi kesulitan belajar pada pembelajaran matematika siswa kelas IV SD Negeri 125 Pekanbaru secara keseluruhan dapat dilihat dari skor persentase adalah sebagai berikut: Perhatian anggota keluarga pada saat anak belajar matematika dengan persentase $12.0 \%$, cara orang tua mendidik dengan persentase $14.2 \%$, fasilitas belajar matematika dengan persentase $11.4 \%$, metode guru dalam mengajar matematika dengan perentase $17.5 \%$, suasana kelas selama pembelajaran matematika dengan persentase $17.2 \%$, teman bermain diluar jam sekolah dengan persentase $14.6 \%$, dan suasana lingkungan rumah dengan persentase $13.1 \%$.

Berdasarkan hasil rekapitulasi presentase tersebut dapat di ambil kesimpulan bahwa faktorfaktor eksternal yang mempengaruhi kesulitan belajar pada pembelajaran matematika siswa kelas IV Sekolah Dasar Negeri 125 Pekanbaru yang paling dominan yaitu metode guru dalam mengajar matematika dan yang paling tidak dominan adalah fasilitas belajar matematika.

Dari hasil pengolahan data angket yang telah dijawab oleh siswa tentang analisis faktorfaktor yang mempengaruhi kesulitan belajar pada pembelajaran siswa kelas IV SD Negeri 125 Pekanbaru terdiri atas perhatian anggota keluarga pada saat anak belajar matematika, cara orang tua mendidik, fasilitas belajar matematika, metode guru dalam mengajar matematika, suasana kelas selama pembelajaran matematika, teman bermain diluar jam sekolah, dan suasana lingkungan rumah.

Perhatian anggoa keluarga pada saat anak belajar matematika merupakan hal penting yang mempengaruhi keberhasilan belajar. Menurut Robert dan Henry (dalam Rofiqul A'la, 2016) tentang perkembangan anak yang tidak mendapat perhatian orang tua, dimana mereka menyimpulkan bahwa anak yang kurang mendapat perhatian orang tua cenderung memiliki kemampuan akademis yang menurun atau prestasi belajar yang kurang baik. Terlihat dari analisis data bahwa beberapa siswa menyatakan orang tua nya jarang mendampingi ketika belajar matematika, hal ini terjadi karena kesadaran orang tua terhadap pendidikan masih rendah serta kesibukan orang tua mereka akan pekerjaannya sehinga tidak ada waktu khusus untuk mendampingi anaknya pada saat belajar dirumah.

Selanjutnya cara orang tua mendidik juga menjadi penyebab kesulitan belajar matematika. Menurut Slameto (2003) cara orang tua mendidik anaknya besar pengaruhnya terhadap belajar anaknya. Dari hasil analisis data terlihat bahwa sebagian orang tua membiarkan anaknya belajar matematika sendiri, tidak pernah tau hasil ulangan matematika siswa serta jarang menanyakan 
kesulitan yang sedang dialami siswa sehingga hal tersebut menjadi penyebab kesulitan belajar matematika siswa kelas IV SD Negeri 125 Pekanbaru.

Selain faktor keluarga, sekolah juga memberikan kontribusi terhadap keberhasilan belajar siswa. Lengkapnya fasilitas belajar akan memudahkan siswa dalam mencapai tujuan belajar. Terlihat dari analisis data yang diperoleh bahwa seluruh siswa memiliki buku paket matematika yang dipinjamkan dari perpustakaan. Papan tulis yang digunakan juga terlihat layak untuk belajar matematika. Akan tetapi Metode guru dalam mengajar matematika menjadi penyebab yang paling dominan mempengaruhi kesulitan belajar matematika yang dialami siswa kelas IV SD Negeri 125 Pekanbaru. Sejalan dengan yang dikemukakan oleh Gunarsa (2000) yaitu faktor sekolah sangat besar pengaruhnya dalam kehidupan siswa karena hampir sepertiga dari kehidupan siswa sehari-harinya berada di sekolah. Suasana kelas selama pembelajaran matematika juga mempengaruhi kesulitan belajar matematika. Dalam perolehan analisis data diketahui bahwa hampir sebagian besar siswa mengatakan sulit belajar matematika karena lingkungan kelas tidak nyaman, karena sekolah dekat dengan lingkungan pasar. Hal tersebut menghambat proses belajar dan mengakibatkan kesulitan dalam belajar matematika.

Selain faktor keluarga dan sekolah, terdapat faktor masyarakat yang juga

\section{SIMPULAN DAN REKOMENDASI}

Berdasarkan data penelitian faktor yang mempengaruhi kesulitan belajar matematika siswa kelas IV SD Negeri 125 diantaranya adalah metode guru dalam mengajar matematika, suasana kelas selama pembelajaran matematika, teman bermain diluar jam sekolah, cara orang tua mendidik, suasana lingkungan rumah, perhatian anggota keluarga pada saat anak belajar matematika, dan fasilitas belajar matematika.

Berdasarkan hasil penelitian, peneliti memberikan beberapa saran yakni: Diharapakan sebagai bahan masukan kepada guru agar menggunakan metode belajar yang sesuai dengan mempengaruhi kesulitan belajar matematika. Sub indikator tersebut adalah teman bermain diluar jam sekolah. Hal tersebut sesuai dengan yang dikemukakan oleh Nini Subini (2012) bahwa salah satu faktor masyarakat yang mempengaruhi kesulitan belajar siswa adalah pergaulan dengan teman. Dalam perolehan analisis data terlihat beberapa siswa menyatakan bahwa temannya sering mengajak untuk tidak mengerjakan PR matematika, dan siswa jarang mengerjakan PR sebelum bermain. Selain itu peran masyarakat juga dapat mempengaruhi siswa dalam belajar. Terlihat dari analisis data yang diperoleh bahwa mereka sangat terganggu pada saat belajar matematika dirumah karena lingkungan rumahnya yang selalu ramai orang.

Adapun dengan mengamati perilaku siswa dan kemampuan siswa dalam belajar dengan demikian sesuai yang dikemukakan oleh Syaiful Bahri (2011), kesulitan belajar adalah suatu kondisi dimana anak didik tidak dapat belajar secara wajar, disebabkan adanya ancaman, hambatan, ataupun gangguan dalam belajar. Untuk mengatasi kesulitan belajar pada siswa, khususnya pada pembelajaran matematika, orang tua harus menumbuhkan rasa semangat untuk belajar, ini merupakan hal yang harus dilakukan oleh orang tua maupun guru. Orang tua ataupun guru harus mendukung dan memotivasi dalam belajar untuk menumbuhkan rasa semangat dalam proses pembelajaran.

pelajaran matematika agar tidak terjadi hambatan dalam belajar yang mengakibatkan kesulitan belajar matematika. Diharapkan dengan adanya penelitian ini dapat sebagai bahan masukan untuk orang tua, agar orang tau berperan aktif dalam memberi perhatian serta memantau pergaulan anak dan memperhatikan anaknya agar anak tidak mengalami hambatan-hambatan atau kesulitan dalam belajar matematika. Diharapkan sebagai bahan informasi bagi peneliti berikutnya untuk menambah wawasan pendidikan di sekolah dasar. Peneliti menyarankan beberapa topik yang dapat dijadikan sebagai penelitian lanjutan. Topik 
tersebut berkaitan dengan kesulitan belajar Bahasa Indonesia untuk Sekolah Dasar kelas V atau dapat juga dengan kesulitan pada mata pelajaran yang lainnya.

\section{DAFTAR PUSTAKA}

Aunurrahman. (2010). Belajar dan Pembelajaran. Bandung: Alfabeta

Djamrah, Syaiful Bahri. (2002). Strategi Belajar Matematika. Jakarta: Rieneka Cipta.

Gunarsa, S.D. (2000). Psikologi Perkembangan. Jakarta: Gunung Mulia

Hamzah, dkk. (2013). Perencanaan dan Strategi Pembelajaran Matematika. Jakarta: PT Grafindo Persada.

Kemendikbud. (2013). Kerangka Dasar dan Struktur Kurikulum 2013. Jakarta: Kemendikbud.

Margono, S. (2000). Metodologi Penelitian Pendidikan. Jakarta: Rineka Cipta.

Mulyono, A. (2010). Pendidikan Bagi Anak Berkesulitan Belajar. Jakarta: Rieneka Cipta.

Rofiqul, A. (2016). Perhatian Orang Tua dan Motivasi Belajar Siswa. Jurnal Madaniyah, 2(11), 242-359.

Slameto. (2003). Belajar dan Faktor-faktor yang Mempengaruhinya. Jakarta: Rieneka Cipta.

Subini, Nini. (2011). Mengatasi Kesulitan Belajar Pada Anak. Jogjakarta: Javalitera

Sudjiono, A. (2011). Evaluasi Pendidikan. Jakarta: Raja Grafindo Persada

Sugiyono. (2015). Metode Penelitian Pendidikan Pendekatan Kuantitatif, Kualitatif dan $R \& D$. Bandung: ALFABETA, cv.

Zulkaidah, W., Marhadi, H., \& Kurniawan, O. (2018). Analisis Cara-Cara Guru Memotivasi Belajar Siswa pada Pembelajaran IPS di Sekolah Dasar Gugus 7 Kecamatan Tampan Kota Pekanbaru. JOM: Jurnal Online Mahasiswa FKIP, 5(1), 1-9. 